\title{
Dual crop coefficient of common bean in Tangará da Serra, Mato Grosso
}

\author{
William Fenner ${ }^{1}$, Rivanildo Dallacort ${ }^{2}$, Paulo S. L. de Freitas ${ }^{3}$, \\ Cleonir A. Faria Júnior ${ }^{4}$, Marco A. C. de Carvalho ${ }^{5}$ \& Guilherme Bariviera $^{6}$ \\ ${ }^{1}$ Universidade do Estado de Mato Grosso/Programa de Pós-graduação em Ambiente e Sistemas de Produção Agrícola. Tangará da Serra, MT. E-mail: \\ fennerwilliam@gmail.com (Corresponding author) \\ ${ }^{2}$ Universidade do Estado de Mato Grosso/Departamento de Agronomia. Tangará da Serra, MT. E-mail: rivanildo@unemat.br \\ ${ }^{3}$ Universidade Estadual de Maringá. Maringá, PR. E-mail: pslfreitas@uem.br \\ ${ }^{4}$ Universidade Estadual de Maringá/Programa de Pós-graduação em Agronomia. Maringá, PR. E-mail: cleonir.junior@hotmail.com \\ ${ }^{5}$ Universidade do Estado de Mato Grosso/Departamento de Agronomia. Alta Floresta, MT. E-mail: marcocarvalho@unemat.br \\ ${ }^{6}$ Universidade do Estado de Mato Grosso. Tangará da Serra, MT. E-mail: guilherme.bariviera@hotmail.com
}

\section{Key words:}

Phaseolus vulgaris

basal crop coefficient evaporation coefficient irrigation

\begin{abstract}
A B S T R A C T
This study aimed to determine the dual crop coefficient of common bean (Phaseolus vulgaris L.) for Tangará da Serra-MT, Brazil. The study used the FAO-56 dual $\mathrm{k}_{\mathrm{c}}$ method, dividing the $\mathrm{k}_{\mathrm{c}}$ into soil evaporation coefficient $\left(\mathrm{k}_{\mathrm{e}}\right)$, determined in microlysimeters, and basal crop coefficient $\left(\mathrm{k}_{\mathrm{cb}}\right)$, determined in weighing lysimeters. The study was conducted from July 10 (sowing) to October 6, 2014 (harvest), using the common bean cultivar 'BRS Estilo' and a sprinkler irrigation system with a coefficient of uniformity greater than $80 \%$. The total rainfall and irrigation during the crop cycle (84 days) was $524.8 \mathrm{~mm}$; the potential evapotranspiration ( $\mathrm{ET}_{\mathrm{o}}$ ) estimated for the period was $327.9 \mathrm{~mm}$, whereas the crop evapotranspiration (ET) accumulated during the cycle, determined in lysimeters, was equal to $477.5 \mathrm{~mm}$. The $\mathrm{k}_{\mathrm{cb}}$ values determined for the initial, full development and final stages were $0.32,1.10$ and 0.81 , respectively, while for $\mathrm{k}_{\mathrm{e}}$, the respective values were $0.85,0.40$ and 0.53 .
\end{abstract}

\section{Coeficiente dual de cultivo do feijoeiro em Tangará da Serra, Mato Grosso}

\section{R E S U M O}

Objetivou-se determinar, na presente pesquisa, o coeficiente duplo de cultivo do feijoeiro (Phaseolus vulgaris L.) na região de Tangará da Serra, MT, Brasil. A metodologia utilizada foi a do $k_{c}$ dual da FAO dividindo-se o coeficiente de cultivo $\left(k_{c}\right)$ em coeficiente de evaporação do solo $\left(\mathrm{k}_{\mathrm{e}}\right)$ determinado em microlisímetros e coeficiente basal da cultura $\left(\mathrm{k}_{\mathrm{cb}}\right)$, determinado em lisímetros de pesagem. A cultivar de feijoeiro utilizada foi a BRS Estilo; o estudo foi realizado no período de 10/07/2014 (semeadura) a 06/10/2014 (colheita); a irrigação por aspersão foi utilizada com coeficiente de uniformidade superior a $80 \%$; a lâmina total precipitada e irrigada durante o ciclo da cultura (84 dias) foi $524,8 \mathrm{~mm}$; a evapotranspiração potencial (ET) estimada no período foi de $327,9 \mathrm{~mm}$ enquanto que a evapotranspiração da cultura (ET) acumulada, determinada em lisímetros, foi de 477,5 $\mathrm{mm}$; $\mathrm{o}_{\mathrm{cb}}$ determinado para as fases inicial, pleno desenvolvimento e final, foi 0,32; 1,10 e 0,81 , respectivamente; para o $\mathrm{k}_{\mathrm{e}}$, os valores foram 0,$85 ; 0,40$ e 0,53 , nas fases inicial, pleno desenvolvimento e final, respectivamente. 


\section{INTRODUCTION}

Brazil stands out in the world for its abundance of water resources, for the use in both energy generation and agriculture, through irrigation. According to FAO (2013), Brazil has the third largest potential of irrigation in the world and is only behind India and China. Given such richness, using it adequately is fundamental for maintaining this potential.

The bean producing area in the state of Mato Grosso corresponds to $69 \%$ of the entire Brazilian Midwest region and represents a value of approximately $14 \%$ of the total national cultivation, considering the sum of the first, second and third (irrigated) seasons. This state alone produces 535,000 $\mathrm{t}$ of bean, which correspond to approximately $61 \%$ of the Midwest production and $16 \%$ of the total Brazilian production. The mean yield in the state is $1,653 \mathrm{~kg} \mathrm{ha}^{-1}$, which is below 2,434 $\mathrm{kg} \mathrm{ha}^{-1}$, of the Goiás state, and 2,084 $\mathrm{kg} \mathrm{ha}^{-1}$, of the Midwest region (CONAB, 2014).

The knowledge on the water consumption of cultivated plants is fundamental for the rational use of water resources and enhancement of cultivation systems. Thus, many studies have been conducted in order to determine crop evapotranspiration and soil water dynamics for the optimization of irrigation systems (Flumignam et al., 2011; Gonçalves et al., 2014; Santos Júnior et al., 2015), as well as to indicate the best cultivation periods, due to the irregularities in the rainfall regimes (Barbieri et al., 2014).

Crop transpiration and water evaporation from the soil constitute the process of evapotranspiration, which can be estimated through different methods or determined under local conditions, through lysimeters; the latter is the most indicated, because of the intrinsic characteristics of each site, such as climate, vegetation and relief (Mendonça et al., 2003; Faria et al., 2006; Santos et al., 2008).

Evapotranspiration components can be determined for different crops, perennial or annual, and the crop coefficient $\left(\mathrm{k}_{\mathrm{c}}\right)$ is the parameter that relates crop evapotranspiration $\left(\mathrm{ET}_{\mathrm{c}}\right)$ to the reference evapotranspiration $\left(\mathrm{ET}_{\mathrm{o}}\right)$. This coefficient can be determined using the dual coefficient method, which establishes the representativeness of soil evaporation $\left(\mathrm{k}_{\mathrm{e}}\right)$ and crop transpiration $\left(\mathrm{k}_{\mathrm{cb}}\right)$ in the evapotranspiration (Allen et al., 1998). Therefore, it is possible to comprehend the actual crop demands and adopt management techniques that allow better use of water, reducing wastes and losses through evaporation.

Given the above, this study aimed to determine the dual crop coefficient of common bean (Phaseolus vulgaris) for the region of Tangará da Serra, in the state of Mato Grosso, Brazil, using load-cell weighing lysimeters.

\section{Material AND Methods}

The study was carried out at the experimental field of the State University of Mato Grosso - UNEMAT, Campus of Tangará da Serra, at the Center of Agro-environmental Research, Studies and Development - CEPEDA, in the Laboratory of Agrometeorology, from July to October 2014.

Close to the experimental area, there is an automatic weather station of the Laboratory of Agrometeorology, located at the geographic coordinates of $14^{\circ} 65^{\prime} 00^{\prime \prime} \mathrm{S}, 57^{\circ} 43^{\prime} 15^{\prime \prime}$
$\mathrm{W}$ and altitude of $440 \mathrm{~m}$, which provided the daily data of temperature, rainfall, solar radiation, wind speed, relative air humidity and atmospheric pressure, used in the estimation of reference evapotranspiration - $\mathrm{ET}_{\mathrm{o}}$, according to the method of Penman-Monteith - FAO (Allen et al., 1998). The region has a dry period (May to September) and a rainy period (October to April), with mean annual rainfall of $1,830 \mathrm{~mm}$ (Dallacort et al., 2011). The soil of the experimental area is classified as dystroferric Red Latosol, with very clayey texture.

Six weighing lysimeters with area of $2.25 \mathrm{~m}^{2}(1.50 \times 1.50$ $\mathrm{m}$ ) and depth of $1.20 \mathrm{~m}$, previously calibrated with coefficients of determination above 0.99, were used (Figure 1).

The experiment used the bean cultivation 'BRS Estilo', recommended for winter sowing in the state of Mato Grosso, with cycle of 85 to 90 days, upright growth and highly productive. Soil correction and fertilization were performed based on soil chemical characteristics and crop fertility requirements. All the cultural practices were performed according to the recommendations for the crop, as proposed by Fancelli (2009). Sowing occurred on July 10, 2014, in rows spaced by $0.45 \mathrm{~m}$, distributing 13 seeds per meter, and harvest occurred on October 6, 2014, completing the cycle in 84 days after sowing.

The coefficients $\mathrm{k}_{\mathrm{cb}}$ and $\mathrm{k}_{\mathrm{e}}$ were estimated and determined daily in the different crop phenological stages, as described by Allen et al. (1998), with later comparison with the values reported in the literature.

Irrigation depth was determined through the evapotranspiration determined in the lysimeters and applied using a sprinkler irrigation system composed of 4 sprinklers (Eco 232 Frabrimar) with $4.0 \times 2.8 \mathrm{~mm}$ nozzles, spaced by 12 x $12 \mathrm{~m}$, with uniformity coefficient higher than $80 \%$. Irrigation interval was equal to 3 days, in order to meet crop water demand. $\mathrm{ET}_{\mathrm{o}}$ was calculated using the equation proposed by Allen et al. (1998).

The dual $\mathrm{k}_{\mathrm{c}}$ of the common bean, which divides $\mathrm{k}_{\mathrm{c}}$ into basal crop coefficient $\left(\mathrm{k}_{\mathrm{cb}}\right)$ and soil evaporation coefficient $\left(\mathrm{k}_{\mathrm{e}}\right)$, was determined using the methodology proposed by the FAO-56 Bulletin, Chapter 7 (Allen et al., 1998). The method consists in the daily estimation of $\mathrm{k}_{\mathrm{cb}}$ and $\mathrm{k}_{\mathrm{e}}$. Meteorological data are used for $\mathrm{ET}_{\mathrm{o}}$ estimation, as well as the tabulated values of $\mathrm{k}_{\mathrm{cb}}$ and $\mathrm{k}_{\mathrm{e}}$, which must be adjusted to each locality; data of equivalent moisture at field capacity $(\theta \mathrm{FC})$, equivalent moisture at permanent wilting point $(\theta \mathrm{PWP})$ and effective root system

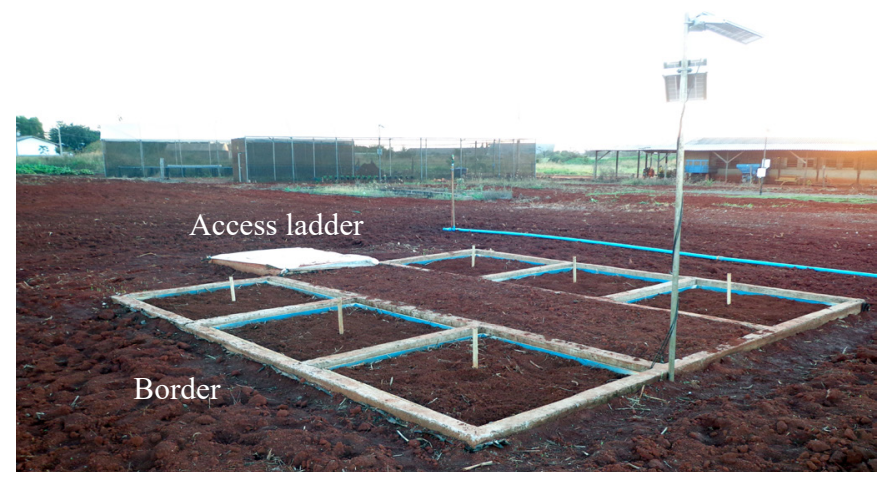

Figure 1. Experimental area, weighing lysimeters and underground access ladder 
depth are necessary in the estimation. The data are inserted in an electronic worksheet, estimating soil cover rate as a function of the increase in leaf area, evaporation reduction coefficient $\left(\mathrm{k}_{\mathrm{r}}\right)$, ETc, $\mathrm{k}_{\mathrm{cb}}$ and $\mathrm{k}_{\mathrm{e}}$ (Allen et al., 1998). The dual $\mathrm{k}_{\mathrm{c}}$ is determined using lysimeters and microlysimeters.

Four microlysimeters with diameter of $150 \mathrm{~mm}$ and height of $200 \mathrm{~mm}$ were used in the determination of soil evaporation and later determination of daily soil evaporation coefficient $\left(\mathrm{k}_{\mathrm{e}}\right)$, according to the methodology proposed and adapted by Flumignam et al. (2012). Soil evaporation $\left(\mathrm{E}_{\mathrm{ML}}\right)$ was determined according to Eq. 1:

$$
\mathrm{E}_{\mathrm{ML}}=\frac{\Delta \mathrm{M}_{\mathrm{ML}}}{\mathrm{A}_{\mathrm{ML}}}+\mathrm{P}
$$

where:

$\mathrm{E}_{\mathrm{ML}}$ - water evaporated from the microlysimeter ( $\left.\mathrm{mm}\right)$;

$\Delta \mathrm{M}_{\mathrm{ML}}$ - mass variation in the microlysimeter $(\mathrm{kg})$;

$\mathrm{A}_{\mathrm{ML}}$ - area of the microlysimeter $\left(\mathrm{m}^{2}\right)$; and,

$\mathrm{P}$ - rainfall (mm).

$\mathrm{k}_{\mathrm{e}}$ was daily calculated through the relationship between soil water evaporation $\left(\mathrm{E}_{\mathrm{ML}}\right)$ and reference evapotranspiration $\left(\mathrm{ET}_{\mathrm{o}}\right)$. Crop evapotranspiration $\left(\mathrm{ET}_{\mathrm{c}}\right)$ was also obtained daily, based on the mass variation of the lysimeters, converted to $\mathrm{mm}$ $\mathrm{d}^{-1}$, according to Allen et al. (1998). Then, $\mathrm{k}_{\mathrm{cb}}$ was determined according to Eq. 2:

$$
\mathrm{K}_{\mathrm{cb}}=\frac{\mathrm{ET}_{\mathrm{c}}}{\mathrm{ET}_{\mathrm{o}}}-\mathrm{ke}
$$

where:

$$
\begin{array}{ll}
\mathrm{k}_{\mathrm{cb}} & \text { - basal crop coefficient; } \\
\mathrm{ET}_{\mathrm{c}} & \text { - crop evapotranspiration }\left(\mathrm{mm} \mathrm{d}^{-1}\right) ; \\
\mathrm{k}_{\mathrm{e}} & \text { - soil evaporation coefficient; and, } \\
\mathrm{ET}_{\mathrm{o}} & \text { - reference potential evapotranspiration. }
\end{array}
$$

The curve of $\mathrm{k}_{\mathrm{cb}}$ and $\mathrm{k}_{\mathrm{e}}$ for the common bean development stages was constructed and the values were compared with those proposed by Allen et al. (1998).

\section{Results AND Discussion}

Daily accumulations of irrigation depth and rainfall and daily means of maximum, medium and minimum temperature for the period from sowing to harvest are shown in Figure 2.

The applied irrigation depth and rainfall corresponded to 474.3 and $50.5 \mathrm{~mm}$, respectively, accounting for a total volume of $524.8 \mathrm{~mm}$ during the cultivation period (Figure 2). In general and according to Fancelli (2009), the bean crop needs $300 \mathrm{~mm}$ during its cycle for optimal development without the need for irrigation.

Bizari et al. (2009), evaluating water consumption and yield of common bean in Campinas-SP, obtained yields of 1,492 and $2,337 \mathrm{~kg} \mathrm{ha}^{-1}$ with water depths of 261.3 and $224.4 \mathrm{~mm}$ in conventional and no-tillage cultivation systems, respectively. In the present study, the mean yield of the bean crop cultivated in load-cell weighing lysimeters was equal to $2,962.35 \mathrm{~kg} \mathrm{ha}^{-1}$, which can be considered as satisfactory for the region, since it is higher than the means of this state $\left(1,653 \mathrm{~kg} \mathrm{ha}^{-1}\right)$ and the state of Goiás $\left(2,434 \mathrm{~kg} \mathrm{ha}^{-1}\right)$, the largest producing region of irrigated bean in the Midwest (CONAB, 2014).

According to Bizari et al. (2009), in the no-tillage system the crop was more efficient at the use of water, for consuming it in smaller amounts, evidencing that the local management system has direct influence on crop evapotranspiration and that the correct management can promote economy in the production system.

For maximum, medium and minimum temperatures, the mean values obtained during the cultivation period were 32.77 , 25.29 and $19.30^{\circ} \mathrm{C}$, respectively. According to Fancelli (2009), the range for the development of common bean is between 15 and $29^{\circ} \mathrm{C}$; thus, the mean temperature of the present study

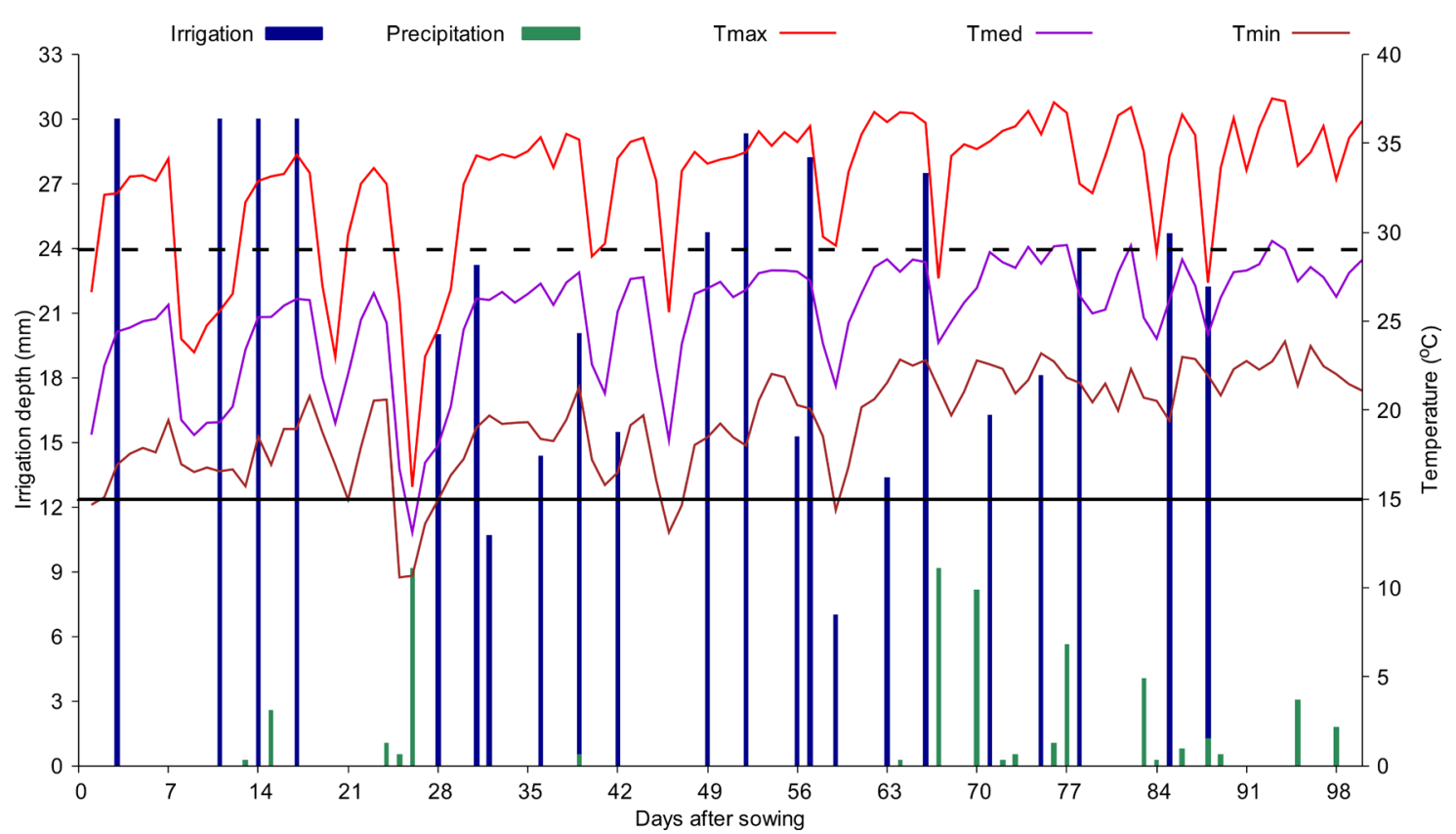

Figure 2. Irrigation depth, maximum, minimum and mean temperature, and interval of development for the period of cultivation of common bean 
is within the optimal range for the crop. It was observed that, in days of rainfall, there is a reduction in the values of maximum and minimum temperature and, consequently, in medium temperature. Such reduction has direct influence and reduces the availability of energy for reference and crop evapotranspiration.

According to Allen et al. (1998), the evapotranspiration rate is strongly influenced by the sensible heat of the air and its interaction of transfer of energy to the crop, influenced by the solar radiation absorbed by the atmosphere and soil temperature, which can increase air temperature. This is a plausible explanation for the greater evapotranspiration in days of higher temperatures, compared with low-temperature and cloudy days. The daily data of ETo, ETc and wind speed for the period from emergence at the field to harvest are shown in Figure 3.

Crop evapotranspiration estimated for the period was 327.9 $\mathrm{mm}$, with maximum of $6.39 \mathrm{~mm} \mathrm{~d}^{-1}$ and minimum of 0.63 $\mathrm{mm} \mathrm{d}^{-1}$ (Figure 3). Crop evapotranspiration, determined in lysimeters, accumulated a total of $477.5 \mathrm{~mm}$, with maximum of $9.53 \mathrm{~mm} \mathrm{~d}^{-1}$ and minimum of $0.60 \mathrm{~mm} \mathrm{~d}^{-1}$. For the studied period, the mean wind speed recorded at the weather station was $2.65 \mathrm{~m} \mathrm{~s}^{-1}$, with maximum of $5.05 \mathrm{~m} \mathrm{~s}^{-1}$ and minimum of $1.51 \mathrm{~m} \mathrm{~s}^{-1}$.

Lima et al. (2013), evaluating water use efficiency with and without mulch for the bean cultivars 'BRS Valente', 'Princesa' and 'Timbó' in Rio Largo-AL, observed total crop evapotranspiration of $393 \mathrm{~mm}$, with maximum of $7.30 \mathrm{~mm}$ $\mathrm{d}^{-1}$ and minimum of $0.80 \mathrm{~mm} \mathrm{~d}^{-1}$; thus, total irrigation of 392 $\mathrm{mm}$ (rainfall + irrigation) is convenient during the crop cycle.

The value found in the present study for crop evapotranspiration in lysimeters was $21.49 \%$ higher than that determined by Lima et al. (2013), which is equivalent to a water depth of $84.47 \mathrm{~mm}$. This may be attributed to the conventional cultivation system in which the study was conducted, the fact that the soil in the lysimeters was always close to field capacity during the cultivation period and the mean temperature of $25.29^{\circ} \mathrm{C}, 1.29^{\circ} \mathrm{C}$ higher than that of these authors, which possibly predisposed the system to higher requirement of water through irrigation.

The real curves of daily $k_{c b}$ and $k_{e}$ for the bean crop in Tangará da Serra-MT are shown in Figure 4. In the initial stage of cultivation, $\mathrm{k}_{\mathrm{e}}$ values are higher than $\mathrm{k}_{\mathrm{cb}}$ values and, when the crop reaches full vegetative development, the opposite occurs. Such behavior is due to the low leaf area index in the initial crop development stage and the soil is the greatest responsible for the evaporation.

$k_{e}$ values are primarily dependent on soil moisture and air humidity, temperature of soil and air, wind and solar radiation. In events of high moisture content in the initial layer, $\mathrm{k}_{\mathrm{e}}$ values tend to be close to 1 , with maximum of 1.2 (Allen et al., 1998). With the reduction in soil moisture in the surface, $\mathrm{k}_{\mathrm{e}}$ tends to decrease and evaporation depends on capillary rise to occur, but with a rate lower than the previous one.

According to Freitas et al. (2014), in a study on soil water evaporation under different mulch fractions (wheat straw) at the Agronomic Institute of Paraná (IAPAR), in Londrina-PR, there are different reductions in soil evaporation for different fractions of soil cover. Evaporation values ranged from 17 to $30 \%, 20$ to $45 \%$ and 30 to $60 \%$ for 50,75 and $100 \%$ of soil cover. The authors attributed these differences to rainfall variations, periods of the day when rainfalls occurred and the fractions of soil cover, which is justified by the fact that soil water evaporation depends on the availability of energy and water. Thus, after irrigation events, if there is availability of energy, evaporation tends to be higher and, therefore, irrigation frequency and climatic conditions directly and significantly influence the evapotranspiration rate of the bean crop, impacting on the increase or reduction of yield or waste of water resource. Thus, by understanding this dynamics, it is possible to take measures and conduct plans to improve the use of water in an irrigated cultivation.

$\mathrm{k}_{\mathrm{cb}}$ behavior is inverse to that of $\mathrm{k}_{\mathrm{e}}$; lower at the beginning of crop development, reaching maximum mean values in the

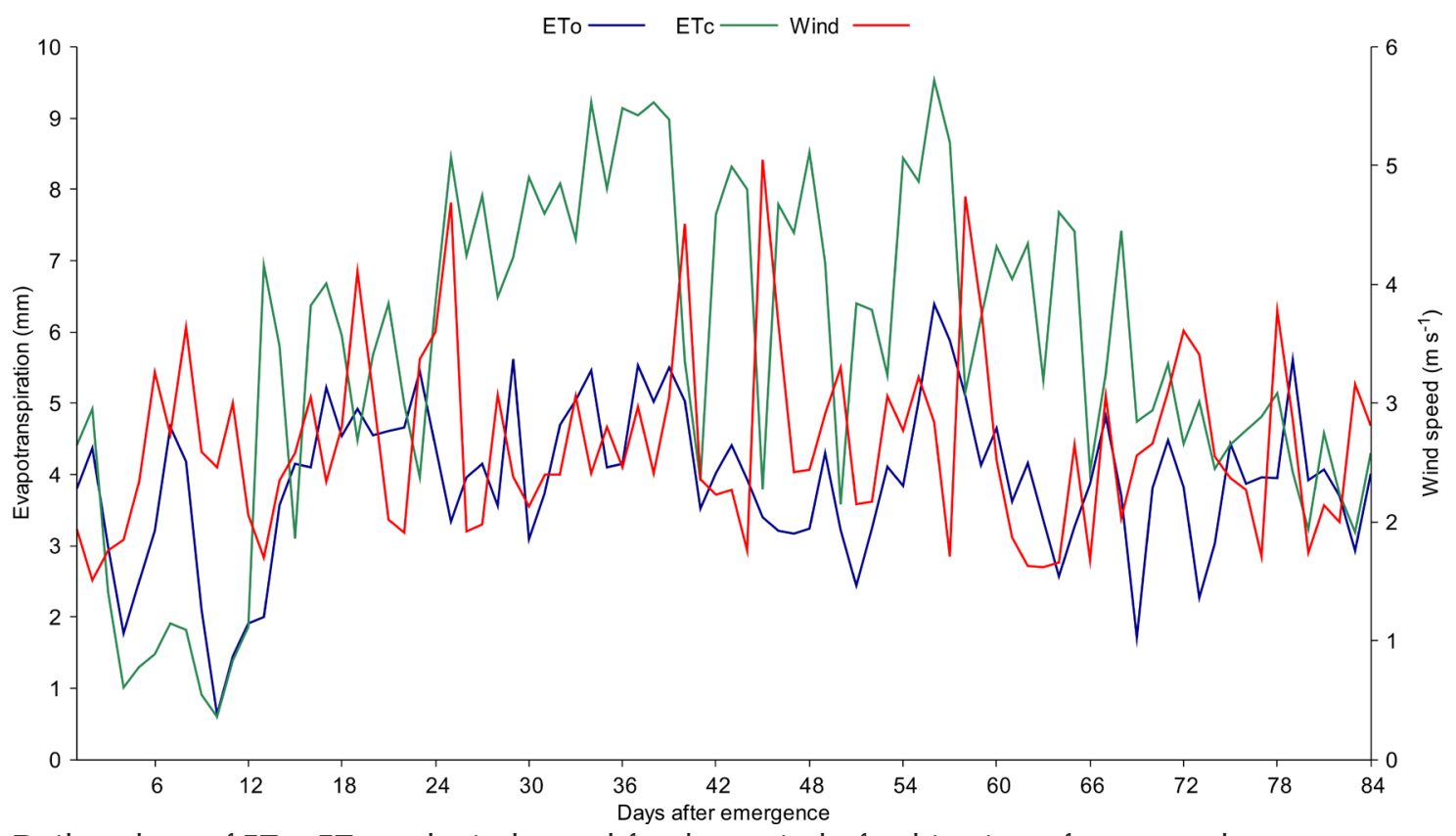

Figure 3. Daily values of ETo, ETc and wind speed for the period of cultivation of common bean 


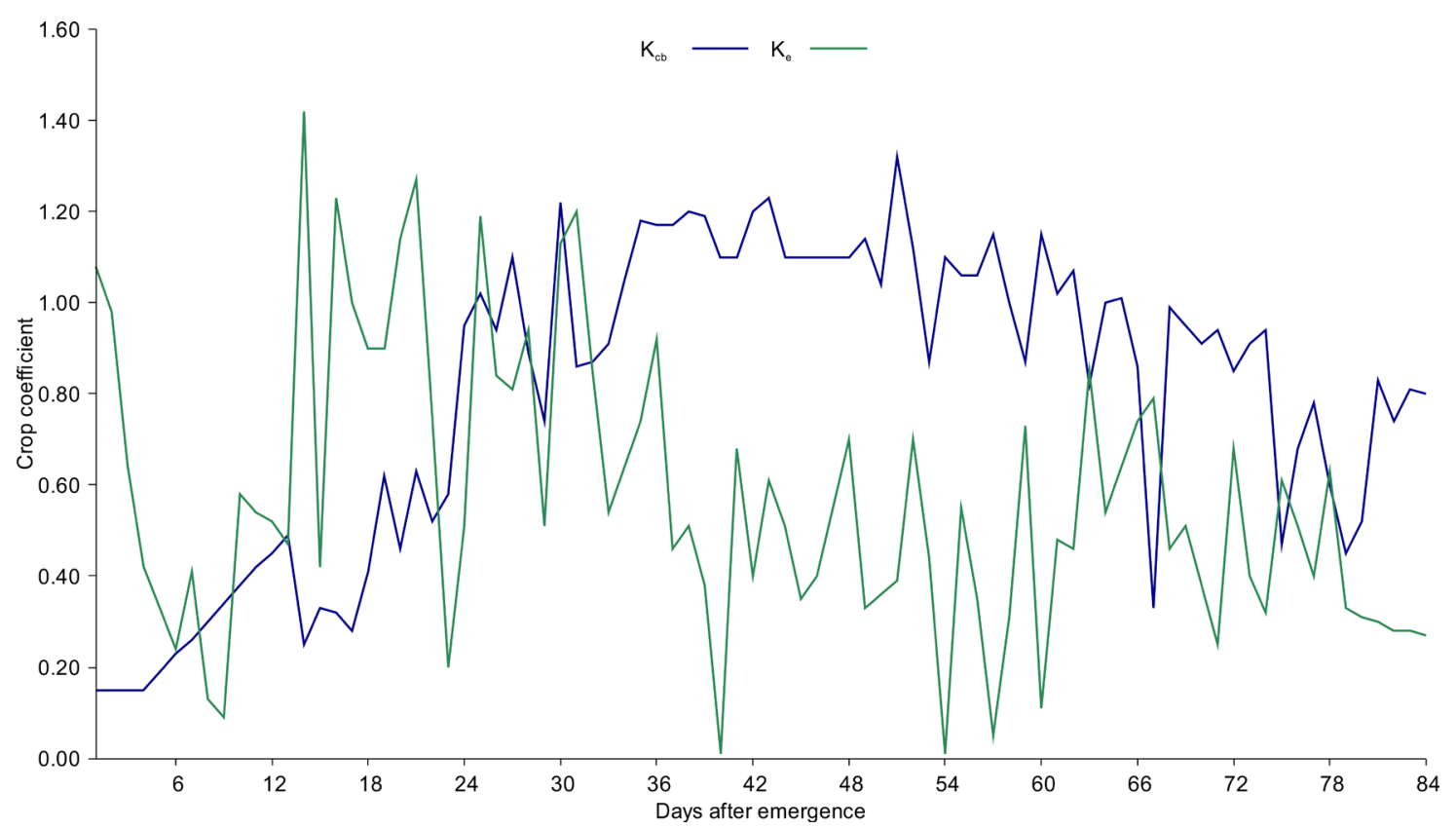

Figure 4. Real curves of daily $\mathrm{k}_{\mathrm{cb}}$ and $\mathrm{k}_{\mathrm{e}}$ for the period of cultivation of common bean

period of full development and decreasing along maturation. The tendency of $\mathrm{k}_{\mathrm{cb}}$ is similar to that of the single $\mathrm{k}_{\mathrm{c}}$, in which the initial value is lower; then, at the vegetative development stage, it increases, reaching its maximum level, and then decreases as the crop starts the maturation stage.

The mean values of $\mathrm{k}_{\mathrm{cb}}$ were $0.32,1.10$ and 0.81 for the initial, full development and maturation stages, respectively; such behavior is characterized by crop growth and development, in which, at full development, the leaf area is larger and the absorption of water and nutrients by the crop root system is also large, resulting in its higher transpiration rate.

In general, for the mean value of $\mathrm{k}_{\mathrm{c}}, \mathrm{k}_{\mathrm{cb}}$ corresponds to $58.21 \%$ and $\mathrm{k}_{\mathrm{e}}$, to $41.79 \%$. These values will depend on the types of crop and cultivation system. For no-tillage systems, soil evaporation values may suffer greater alterations, because the cover alters the dynamics of soil temperature and water availability. Hence, the entire process of evaporation will be affected (Allen et al., 1998).

The observed and estimated $\mathrm{k}_{\mathrm{cb}}$ and $\mathrm{k}_{\mathrm{e}}$ coefficients and the difference between them are shown in Table 1. Greater differences between observed and estimated data refer to $\mathrm{k}_{\mathrm{e}}$ values, indicating higher tendency of variability in soil evaporation values compared with the transpiration of the bean crop. The values of $\mathrm{k}_{\mathrm{cb}}$ were 0.32 , in the initial development stage, 1.10 at full development and 0.81 in the maturation stage, which were $0.03,0.03$ and 0.16 lower than the estimated

Table 1. Basal crop coefficient, soil evaporation coefficient and single crop coefficient obtained and estimated

\begin{tabular}{cccc}
\hline \multirow{2}{*}{ Coefficient } & \multicolumn{3}{c}{ Development stages } \\
\cline { 2 - 4 } $\mathrm{K}_{\mathrm{cb}}$ & Initial & Full & Maturation \\
Observed & 0.32 & 1.10 & 0.81 \\
Estimated & 0.35 & 1.13 & 0.97 \\
Difference & -0.03 & -0.03 & -0.16 \\
\hline $\mathrm{K}_{\mathrm{e}}$ & & & \\
Observed & 0.85 & 0.40 & 0.53 \\
Estimated & 0.48 & 0.10 & 0.20 \\
Difference & 0.37 & 0.30 & 0.33 \\
\hline
\end{tabular}

values, according to the methodology of Allen et al. (1998). The coefficients of soil water evaporation showed inverse behavior, in relation to basal crop coefficient, and were equal to 0.85 , 0.40 and 0.53 for the initial, full development and maturation stages, respectively, while the respective estimated values were $0.48,0.10$ and 0.20 , with differences of $0.37,0.30$ and 0.33 for the same crop development stages.

These differences may be attributed to specific characteristics of cultivars and regional climatic peculiarities that can favor the greater potential of evapotranspiration in the region of Tangará da Serra-MT.

Therefore, it is evident the importance of the correct management and the design of irrigation systems, as well as studies on rational use of water resources, because the underestimation of actual crop water demands leads to reduction in production and increase in costs, due to the underutilization of inputs for the production, besides not using the maximum potential of the cultivation area.

\section{Conclusions}

1. The $\mathrm{k}_{\mathrm{cb}}$ found for the initial, full development and final stages of common bean were $0.32,1.10$ and 0.81 , respectively.

2. The observed soil evaporation coefficients $\left(\mathrm{k}_{\mathrm{e}}\right)$ for the initial, full development and final stages were $0.85,0.40$ and 0.03 , respectively.

3. The estimated $\mathrm{k}_{\mathrm{cb}}$ for the initial, full development and final stages was close to the determined values. The model underestimated $\mathrm{k}_{\mathrm{e}}$ in relation to the observed values.

\section{ACKNOWLeDgments}

To the financial support of the research project 'Aplicação e transferência de tecnologias na otimização de sistemas agrícolas sustentáveis', 564112/2010-0 CNPq Process, MCT/ CNPq/FNDCT/FAPs/MEC/CAPES/PRO-CENTRO-OESTE Call No 031/2010. 
To the Coordination for the Improvement of Higher Education Personnel (CAPES) for granting the scholarship.

\section{Literature Cited}

Allen, R. G.; Pereira, L.; Raes, D.; Smith, M. Crop evapotranspiration: Guidelines for computing crop water requirements. Rome: FAO, 1998. 326p. Irrigation and Drainage Paper 56

Barbieri, J. D.; Dallacort, R.; Santi, A.; Marco, K. de.; Modolo, A. J.; Júnior, S. S.; Rocha, R. P.; Tieppo, R. C. Sowing dates and plant density of peanut cultivars in different soil and climatic conditions of Mato Grosso state, Brazil. Journal of Food, Agriculture e Environment, v.12, p.269-275, 2014.

Bizari, D. R.; Matsura, E. E.; Roque, M. W.; Souza, A. L. Consumo de água e produção de grãos do feijoeiro irrigado em sistemas plantio direto e convencional. Ciência Rural, v.39, p.2073-2079, 2009. http://dx.doi.org/10.1590/S0103-84782009000700018

CONAB - Companhia Nacional de Abastecimento. Feijão: Série histórica de produção. <http://www.conab.gov.br/ conteudos.php? $\mathrm{a}=1252 \& \mathrm{t}=\&$ Pagina_objcmsconteudos=2\#A_ objcmsconteudos>. 12 Dez. 2014

Dallacort, R.; Martins J. A.; Inoue, M. H.; Freitas, P. S. L.; Coletti, A. J. Distribuição das chuvas no município de Tangará da Serra, médio norte do Estado de Mato Grosso, Brasil. Acta Scientiarum Agronomy, v.33, p.193-200, 2011. http://dx.doi.org/10.4025/ actasciagron.v33i2.5838

Fancelli, A. L. Feijão: Tópicos especiais de manejo. 1.ed. Piracicaba: ESALQ/USP/L, 2009. 208p.

FAO - Food and Agriculture Organization of the United Nations Statistical yearbook 1.ed. Rome: FAO 2013. 307p.

Faria, R. T.; Campeche, F. S. M.; Chibana, E. Y. Construção e calibração de lisímetros de alta precisão. Revista Brasileira de Engenharia Agrícola e Ambiental, v.10, p.237-242, 2006. http://dx.doi. org/10.1590/S1415-43662006000100035
Flumignam, D. L.; Faria, R. T.; Lena, B. P. Test of a microlysimeter for of soil evaporation. Engenharia Agrícola, v.32, p.80-90, 2012. http://dx.doi.org/10.1590/S0100-69162012000100009

Flumignan, D. L.; Faria, R. T.; Prete, C. E. C. Evapotranspiration components and dual crop coefficients of coffee trees during crop production. Agricultural Water Management, v.98, p.791-800, 2011. http://dx.doi.org/10.1016/j.agwat.2010.12.002

Freitas, P. S. L.; Gava, R. A.; Faria, R. T.; Rezende, R.; Vieira, P. V. D. Soil evaporation under different straw mulch fractions. African Journal of Agricultural Research, v.9, p.1793-1800, 2014. http:// dx.doi.org/10.5897/AJAR2013.7854

Gonçalves, A. C. A.; Alves, D. S.; Marques, P. A. A.; Folegatti, M. V.; José, J. V. Distribution of water in Sandy soil applied by drip. Engenharia Agrícola, v.3, p.1175-1185, 2014. http://dx.doi. org/10.1590/S0100-69162014000600013

Lima, R. A. S.; Silva, S.; Santos, M. A. L.; Dantas Neto, J.; Wanderley, J. A. C.; Alvino, F. C. G. Eficiência do uso da água por cultivares de feijão (Phaseolus vulgaris L.) com e sem cobertura morta. Agropecuária Científica no Semiárido - ACSA, v.9, p.18-25, 2013.

Mendonça, J. C.; Souza, E. F.; Bernardo, S.; Dias, G. P.; Grippa, S. Comparação entre métodos de estimativa da evapotranspiração de referência (ETo) na região Norte Fluminense, RJ. Revista Brasileira Agrícola e Ambiental, v.7, p.275-295, 2003. http:// dx.doi.org/10.1590/S1415-43662003000200015

Santos, F. X.; Rodrigues, J. J. V.; Montenegro, A. A. A.; Moura, R. F. Desempenho de lisímetro de pesagem hidráulica de baixo custo no semiárido nordestino. Engenharia Agrícola, v.28, p.115-124, 2008. http://dx.doi.org/10.1590/S0100-69162008000100012

Santos Júnior, J. L. C.; Frizone, J. A.; Paz, V. P. Water use optimization through alternative water depths in the Formoso Irrigation District. Revista Brasileira de Engenharia Agrícola e Ambiental, v.19, p. 621-629, 2015. http://dx.doi.org/10.1590/1807-1929/ agriambi.v19n7p621-629 